\title{
PERKAMBANGAN AGAMA DAN MORAL YANG TIDAK TERCAPAI PADA ANAK USIA DINI
}

\author{
Nur Tanfidiyah \\ Program Magister PIAUD FITK UIN Sunan Kalijaga Yogyakarta \\ E-mail: nurtanfidiyah@yahoo.co.id
}

Article received: 17 Agustus 2017 Review process: 15 Januari 2018

Article published: 30 March 2018

\begin{abstract}
This research discuss religion and moral development of students of kindergarten in TK $A$ $n$ Dasari Budi Krapyak Yogyakarta. This research is descriptive qualitative. The data is acquired from interview, observation, and another data collecting which is support this research. The result of this research is (1) Religion and moral development development which are not achieved by student of kindergarten in class A1 TK Masyitoh nDasari Budi Yogykarta, they are: only knowing religion and God trough song, they do not accustom to have worshipping activities, they have not understood what is good attitude, they have not been able to defferentiate between good attitude and bad attitude, and they have not know much about religious ritual but they have not known Islamic day celebrations; and they not known about the other religions. (2) They need to be given knowledge about children education and increasing affection and togetherness.
\end{abstract}

Key word: Religion and moral development, student of Kindergarten

\begin{abstract}
Abstrak
Penelitian (artikel) ini membahas tentang perkembangan agama dan moral pada anak usia dini di TK A nDasari Krapyak Yogyakarta. Penelitian ini adalah penelitian kualitatif deskriptif. Data diperoleh dari wawancara, observasi, dan pengumpulan data-data yang mendukung penelitian. Hasil penelitian adalah (1) Perkembangan agama dan moral yang tidak tercapai pada AUD di kelas TK A1 Masyitoh nDasari Budi Yogyakarta diantaranya; hanya mengetahui agama dan Tuhanya lewat menyanyi, tidak membiasakan diri beribadah, belum memahami perilaku mulia, belum dapat membedakan perilaku yang baik dan buruk, dan sedikit sekali mengenal ritual kegamaan tetapi belum mengenal hari besar Islam; serta belum mengetahui agama orang lain. (2) perlu pengetahuan pemberikan tentang pendidikan anak dan meningkatkan kasih sayang serta kebersamaan dengan anak-anak.
\end{abstract}

Kata Kunci: Perkembangan Agama, Moral, Anak Usia Dini

\section{PENDAHULUAN}

Merambahnya ekonomi ASEAN telah memberikan dampak nyata yang besar bagi masyarakat, terkhusus masyarakat Indonesia. Di mana masyarakat mulai dihadapkan pada situasi yang gawat. Sebab semua hal dengan mudah masuk dalam suatu negara baik ekonomi, sosial, 
dan paling utama adalah budaya. Budaya Indonesia adalah budaya yang dikenal dengan ramah tamahnya, sopan santunnya, dan penduduk mayoritas beragama Islam yang kental akan toleransinya. Dikhawatirkan dengan masuknya budaya asing akan menggerogoti nilai-nilai budaya tersebut. Sehingga merusak citra budaya Indonesia.

Bersamaan dengan itu, Ilmu Pengetahuan dan Teknologi (IPTEK) turut mempengaruhi kehidupan masyarakat, beberapa diantaranya menjadikan masyarakat enggan bergerak, bersosialisasi, dan merasa ketergantungan. Ditambah media masa kini menyediakan situs porno dan foto-foto yang tidak pantas untuk dilihat. Tidak dipungkiri berdampak buruk pada masyarakat itu sendiri, dengan rusak dan bergesernya arti penting nilai agama dan moral terutama pada jenjang pendidikan anak usia dini sebagai tunas-tunas bangsa. Sebab pada masa inilah anak dalam perkembangan dan pertumbuhan yang sangat pesat, rasa ingin tahu yang tinggi dan keinginan untuk bereksplorasi. Jika sejak dini anak dihadapkan pada keadaan yang mengenaskan tersebut, maka dipastikan anak menjadi manusia dewasa yang tidak berkarakter.

Senada dengan hal di atas, nilai agama dan moral terkhusus pada anak usia dini diartikan sebagai perubahan psikis yang dialami oleh anak usia dini terkait dengan kemampuannya dalam memahami dan melakukan perilaku yang baik berdasarkan ajaran agama yang diyakininya. Dalam sudut pandang Islam, upaya melakukan perilaku yang baik dan menghidari perilaku yang buruk tersebut sering diistilahkan dengan taqwa. Taqwa dapat diartikan dengan awas, hati-hati, menjaga diri, memelihara dan keselamatan diri yang dapat diusahakan dengan melakukan hal yang baik dan yang benar, menjauhi yang jahat dan yang salah (Wiyani, 2014: 175). Adapun nilai agama dan moral adalah pondasi awal dalam membenahi diri untuk mengatasi kemungkinan-kemungkinan buruk yang akan mereka jumpai dikehidupan sehari-hari. John Lock memperkuat pentingnya pendidikan akhlak/moral, menurutnya "Sesungguhnya keutamaan itu (akhlak) adalah sesuatu yang wajib kita jadikan tujuan pendidikaan". Selanjutnya Thomas Aquinas (1225-1273M) menyatakan bahwa "sesungguhnya tujuan pendidikan dan tujuan hidup itu adalah merealisasikan kebahagiaan dengan cara menanamkan keutamaan akal dan akhlak (moral)". Beliau berpendapat bahwa tujuan agama pada masa Isa Al-Masih mulai timbul pada masa-masa dekandansi moral.

Tergesernya nilai agama dan moral tersebut dapat dibuktikan dari beberapa kasus diantaranya; dari berita detik.com (16/05/2014) tentang survei RI-UNICEF tahun 2014 menyatakan, bahwa 1,5 juta remaja alami kekerasan seksual 1 tahun terakhir. Survei ini digelar oleh Pemerintah RI yakni Kementerian Sosial, Kementerian Pemberdayaan Perempuan dan 
Perlindungan Anak (KPPPA), Badan Perencanaan Pembangunan Nasional (Bappenas), Badan Pusat Statistik (BPS) dengan dukungan teknis dari UNICEF Indonesia dan Center for Disease Control and Prevention (CDC). Masa survei ini adalah Maret-April 2014. Jumlah sampel responden diambil secara acak dari 25 provinsi, 108 kabupaten, dan 125 kecamatan dan didapatkan 11.250 responden berusia 13-24 tahun. Metode survei dilakukan pendekatan rumah tangga melalui wawancara. Margin of error $0,05 \%$ dengan tingkat kepercayaan 95\%. Kekerasan yang dialami meliputi kekerasan seksual, fisik, atau emosional.

Kasus lain dari metro.sindonews.com (16/04/2017), menyatakan bahwa Ketua Komisi Nasional Perlindungan Anak (Komnas PA), Arist Merdeka Sirait mengatakan, Saat ini kasus kekerasan pada anak meningkat tajam. Sejak tahun 2010 hingga 2015, lebih dari 10 juta anak menjadi korban kekerasan, 58\% di antaranya menjadi korban kekerasan seksual.

Hingga sekarang ini merambah pada masalah bullying, narkoba, klithih, mencuri, dan lainnya yang semakin menggelisahkan bangsa Indonesia. Sekiranya masalah tersebut menunjukkan bahwa lembaga pendidikan belum sepenuhnya mampu menanamkan agama dan moral pada masyarakat sebagai pondasi dasar dalam berperilaku. Dikatakan bahwa selain masalah kualitas dari aspek kognitif-intelektual, masalah yang paling krusial adalah rendahnya kualitas akhlak dan karakter yang dimiliki keluaran lembaga pendidikan (Yusuf, 2014:54). Selain itu, penyimpangan nilai agama dan moral pada lingkungan yang lebih kecil mulai terlihat dari proses pembelajaran. Adapun pembelajaran adalah proses transfer ilmu pengetahuan yang darinya akan mengembangkan pola pikir anak dan menghasilkan perubahan perilaku. Permasalahan pendidikan nilai agama dan moral menjadi semakin urgen untuk ditelusuri secara dalam, agar mengetahui akar permasalahannya. Sebelum melakukan analisis lebih lanjut, perlu kiranya mendalami tentang agama dan moral serta hal lain yang turut mendukung.

\section{MEMAHAMI PERKEMBANGAN AGAMA DAN MORAL}

Agama merupakan fakta sejarah yang sama tuanya dengan sejarah manusia. Tidak sedikit ilmuwan yang sudah mendefinisikan agama, namun definisi tersebut tidak selalu mencakup semua gejala agama. Kelemahan utama dari pendefinisian agama ialah subjektivitas dari perumus definisi agama itu sendiri (Syamsudin, 2016:765). Agama berasal dari bahasa Sansekerta, yang terdiri dari kata " $a$ " yang berarti tidak dan "gam" yang berarti pergi. Jadi secara bahasa agama dapat diartikan dengan tidak pergi, tetapi di tempat, langgeng, abadi, yang diwariskan secara terus menerus dari satu generasi ke generasi lainnya. Ada juga yang 
mengartikan dengan "gama" yang berarti kacau, sehingga secara bahasa agama diartikan dengan tidak kacau. Ini berarti orang yang beragama hidupnya tidak akan mengalami kekacauan (Wiyani, 2014:174). Sedangkan istilah moral berasal dari bahasa Latin mos (moris), yang berarti adat istiadat, peraturan, nilai-nilai atau tata cara kehidupan (Jahja, 2011: 50). Sama halnya dengan Mores yang artinya: tata-cara dalam kehidupan, adat-istiadat, kebiasaan (Gunarsah, 2003: 38). Adapun moralitas artinya keadaan nilai-nilai moral dalam hubungan dengan kelompok sosial. Moral juga diartikan sebagai karakter atau watak seseorang. Seseorang tidak berakhlak dengan akhlak orang lain, artinya tidak boleh dipaksakan watak pada diri anak-anak. Sedangkan watak itu sendiri terbentuk dari mata hati orang itu sendiri dan dengan watak tersebut seseorang dapat membedakan antara hal yang baik dan yang buruk, inilah pendapat dari Keneth, Socrates, dan Sabinsar (Syantut, 1998: 80).

Berdasarkan deskripsi di atas, maka perkembangan moral dan agama pada anak usia dini dapat diambil kesimpulan sebagai perubahan psikis yang dialami oleh anak usia dini terkait dengan kemampuannya dalam memahami dan melakukan perilaku yang baik serta memahami dan menghindari perilaku yang buruk berdasarkan ajaran agama yang diyakininya. Dalam sudut pandang Islam, upaya melakukan perilaku yang baik dan menghindari perilaku yang buruk tersebut sering diistilahkan dengan takwa. Takwa dapat diartikan dengan awas, hati-hati, menjaga diri, memelihara dan keselamatan diri yang dapat diusahakan dengan melakukan hal yang baik dan yang benar, menjauhi yang jahat dan yang salah (Wiyani, 2014: 175).

\section{Konsep Pendidikan Anak Usia Dini}

Pendidikan anak usia dini (early childhood education) merupakan suatu disiplin ilmu pendidikan yang secara khusus memperhatikan, menelaah, dan mengembangkan berbagai interaksi edukatif antara anak usia dini dengan pendidik untuk mencapai pertumbuhan dan perkembangan potensi anak secara optimal (Wiyani dan Banawi, 2012:46). Pendidikan anak usia dini sebagai pendidikan yang diselenggarakan sebelum jenjang pendidikan dasar, memiliki kelompok sasaran anak usia 0-6 tahun yang merupakan masa keemasan "golden age". Pada masa ini anak-anak masih sangat rentan, yang apabila menanganinya tidak tepat justru dapat merugikan anak tersebut. Oleh karena itu, pendekatan pembelajaran pendidikan anak usia dini harus sesuai dengan tahap-tahap perkembangan. Adapun pendidikan anak usia dini bertujuan untuk memfasilitasi anak untuk lebih memiliki kesiapan baik secara fisik, mental, maupun sosial atau emosional dalam rangka memasuki jenjang pendidikan lanjut (Wahyuni, 2012:2). Dengan 
kata lain PAUD merupakan pondasi dasar dalam pertumbuhan dan perkembangan anak yang sangat fundamental, juga sebagai kerangka dasar terbentuknya dan berkembangnya dasar-dasar pengetahuan, sikap, dan keterampilan pada anak (Purnamasari dkk, 2014:2).

Ada sembilan faktor yang dapat memberikan pengaruh terhadap perkembangan agama dan moral anak, yaitu: 1) Kurang tertanamnya jiwa agama pada setiap orang pada suatu lingkungan tertentu. 2) Keadaan sosial, ekonomi, politik, dan keamanan masyarakat yang kurang stabil. 3) Banyaknya tulisan dan gambar yang tidak mengindahkan ajaran agama dan dasar moral. 4) Tidak terlaksananya pendidikan agama dan budi pekerti dengan baik. 5) Kurangnya kesadaran orang tua akan urgensi pendidikan agama dan budi pekerti bagi anak. 6) Banyak orang yang mengabaikan untuk berbuat baik. 7) Suasana rumah tangga yang kurang baik. 8) Kurang adanya bimbingan untuk mengisi waktu luang bagi anak. 9) Kurangnya tempat pemberian layanan bimbingan serta tenaga layanan bimbingan anak (Wiyani, 2014: 132-133).

\section{Tahap Perkembangan Agama dan Moral pada Anak Usia Dini}

Melalui pengenalan konsep-konsep keagamaan pada anak, maka akan mempengaruhi segi perkembangan afektifnya. Perkembangan agama pada anak dapat melalui beberapa fase, yaitu : 1) The Fairy Tale Stage ( Tingkatan Dongeng). Pada tingkat ini dimulai pada usia 3-6 tahun. Anak dalam tingkatan ini, konsep mengenai ketuhanan lebih banyak dipengaruhi oleh fantasi dan emosi. Konsep ini sesuai dengan perkembangan intelektualnya. 2) The Realistic Stage (Tingkatan Kenyataan). Tingkatan ini dimulai sejak SD. Pada masa ini ide ketuhanan anak sudah mencerminkan konsep-konsep yang berdasarkan pada kenyataan. Konsep ini timbul melalui lembaga keagamaan dan pembelajaran agama. 3) The Individual Stage (Tingkatan Individu). Pada tingkat ini anak memiliki kepekaan emosi yang tinggi sejalan dengan perkembangan usia mereka. Ada beberapa alasan mengenalkan nilai-nilai agama kepada anak usia dini, yaitu anak mulai minat, semua perilaku anak membentuk suatu pola perilaku, mengasah potensi positif diri, sebagai individu makhluk sosial dan hamba Allah. Agar perkembangan agama pada anak tumbuh subur, harus dilatih dengan cara menyenangkan agar anak tidak merasa terpaksa dalam melakukan kegiatan. Sesuai ciri-ciri yang anak miliki, ide keagamaan anak hampir sepenuhnya otoritas. Maksudnya konsep keagamaan pada diri mereka dipengaruhi oleh faktor dari luar diri mereka. Bagi mereka sangat mudah menerima ajaran dari orang dewasa walaupun belum mereka sadari sepenuhnya manfaat ajaran tersebut (Mursid, 2015:89). 
Kemudian setidaknya ada dua teori yang mengungkapkan munculnya keagamaan pada anak, yaitu: Pertama, Rasa ketergantungan (sense of depende). Manusia dilahirkan ke dunia ini memiliki empat kebutuhan, yakni keinginan untuk perlindungan (security), keinginan akan pengalaman baru (new exprerience), keinginan untuk mendapat tanggapan (respon), dan keinginan untuk dikenali (recognition). Berdasarkan pernyataan dan kerjasama dari keinginan tersebut, maka bayi sejak dilahirkan hidup dalam ketergantungan. Melalui pengalamanpengalaman yang diterimanya dari lingkungan itu kemudian terbentuklah rasa keagamaan pada diri anak. Kedua, Instink Keagamaan. Bayi yang dilahirkan sudah memiliki beberapa instink, diantaranya instink keagamaan. Belum terlihatnya tindak keagamaan pada diri anak karena beberapa fungsi kejiwaan yang menopang kematangan berfungsinya instink itu belum sempurna. Dengan demikian pendidikan agama perlu diperkenalkan kepada anak jauh sebelum anak berusia 7 tahun. Artinya jauh sebelum usia tersebut, nilai-nilai agama perlu ditanamkan kepada anak sejak dini. Nilai kegamaan itu sendiri bisa berarti perbuatan yang berhubungan antara manusia dengan Tuhan atau hubungan antar-sesama manusia (Mansur, 2011:47-48).

Sejalan dengan deskripsi di atas, menurut Kohlberg ada tiga tahapan perkembangan moral yaitu sebagai berikut:

Pertama, Tingkat Tahapan Prakonvensional. Aturan ini berisi tentang ukuran moral yang dibuat otoritas oleh lembaga terkait. Pada tahapan perkembangan ini anak-anak tidak akan melanggar ketentuan yang berlaku dilembaga dikarenakan merasa takut atas ancaman dan hukuman yang telah ditentukan oleh lembaganya, sehingga anak secara tidak sadar dituntut untuk melaksanakan peraturan dan takut melakukan larangan yang ada. Imbasnya anak akan selalu melakukan perbuatan yang baik dan meninggalkan yang jelek. Kohlberg menurutnya, perkembangan moral yang terjadi pada anak dipengaruhi oleh berbagai aktivitas anak yang terikat oleh peraturan orang tua mereka. Tingkatan yang pertama ini dibagi menjadi dua tahap lagi, yaitu sebagai berikut: a) Tahap orientasi terhadap kepatuhan dan hukuman, pada tahap ini anak hanya mengetahui bahwa aturan-aturan yang ada ini ditentukan oleh adanya kekuasaan yang mana tidak bisa diganggu gugat oleh siapapun. Jadi dalam tahapan ini mau atau tidak anak akan mendapatkan hukuman sesuai dengan pelanggaran yang dilakukan. Suatu kegiatan yang membuat ibu marah dianggap salah dan suatu kegiatan yang membuat ibu senang dianggap baik atau benar. b) Tahap relavistik, pada tahap ini anak tidak lagi secara mutlak tergantung pada peraturan yang berlaku di luar dirinya yang dilakukan oleh orang lain yang melakukan otoritas. Jadi dalam hal ini anak sudah memulai sadar bahwa setiap kejadian mempunyai beberapa segi 
yang bergantung pada kebutuhan (relavitisme) orang yang membuat peraturan dan kesenangan seseorang (Mansur, 2011: 77).

Pada tingkatan pra-konvensional ini anak belum menunjukkan kemampuan pengenalan terhadap baik-buruk dan benar-salah dengan kokoh. Namun pada sebagian anak usia dini, ada yang sudah memiliki kepekaan atau sensivitas yang tinggi dalam merespon lingkungannya dengan respon positif dan respon negatif. Misalnya ketika pendidik PAUD atau orang tua membiasakan anak-anaknya untuk berperilaku baik seperti mencium tangan orang tua ketika berjabat tangan, mengucapkan salam ketika akan berangkat dan pulang sekolah, mengucapkan terima kasih setelah mendapat bantuan dari orang lain, mengucapkan maaf atas kesalahannya, dan contoh-contoh positif lainnya, maka dengan sendirinya perilaku seperti itu akan terinternalisasi dalam diri anak sehingga menjadi suatu kebiasaan mereka sehari-hari. Demikian pula sebaliknya, jika kebiasaan negatif itu dibiasakan pada kepada anak maka perilaku negatif itu akan terinternalisasi pula dalam dirinya (Wiyani, 2014:136).

Kedua, Tingkat Tahapan Konvensional. Dalam hal ini anak dituntut untuk mematuhi peraturan yang telah disepakati bersama-sama agar dia mau diterima di kelompok sebayanya. Kelompok ini terdiri dari dua tahap: a) Tahap orientasi mengenai anak yang baik: dalam tahapan ini anak mulai memperhatikan orientasi terhadap perbuatan yang dinilai baik atau tidak baik oleh orang lain atau sekitarnya. Sesuatu dikatakan baik dan benar apabila segala sikap dan perilaku atau perbuatannya dapat diterima oleh orang lain atau sekitarnya. b) Tahapan mempertahankan norma sosial dan otoritas: pada tahapan ini anak-anak mulai menunjukkan perbuatan yang benarbenar bukan hanya agar diterima oleh lingkungan atau sekitarnya saja, tetapi juga bertujuan agar dirinya dapat ikut serta mempertahankan atauran dan norma atau nilai sosial yang ada sebagai kewajiban dan tanggung jawab moral untuk melaksanakan peraturan yang ada (Mursid, 2015:78).

Ketiga, Tingkat Tahapan Pascakonvensional. Pada tahap ini anak mematuhi peraturan untuk menghindari hukuman kata hatinya. Tingkatan ini juga terdiri dari dua tahap yaitu: (a) Tahap orientasi terhadap perjanjian antara dirinya dengan lingkungan sosialnya. Pada tahap ini ada hubungan timbal balik antara dirinya dengan lingkungan sosial dan masyarakat. Jadi dalam tahap ini anak akan menaati aturan sebagai kewajiban dan tanggung jawab atas dirinya dalam menjaga keserasian hidupnya di sekitarnya. (b) Tahapan universal: pada tahap ini selain ada norma pribadi yang bersifat subjektif ada pula norma etik (baik atau buruk, benar atau salah) 
yang bersifat universal sebagai sumber menentukan suatu perbuatan yang berhubungan dengan moralitas (Mursid, 2015:78-79).

Perkembangan moral yakni suatu proses perkembangan mental yang berhubungan dengan perubahan-perubahan cara anak berkomunikasi dengan orang lain, baik sebagai individu maupun kelompok. Namun menurut J. Buul, perkembangan moral dibagi menjadi empat (4) yaitu sebagai berikut: 1) Tahap Anomi. Ketidakmampuan moral bayi. Moral bayi barulah suatu potensi yang siap dikembangkan dalam lingkungan. Artinya, bayi lahir dalam keadaan fitrah (mempunyai potensi) yang selalu siap untuk dikembangkan. Jadi tergantung yang mau memberi warna kehidupan, sikap, perilaku, moral yang akan ditanamkan sejak dini pada dirinya. 2) Tahap Heteromoni. Moral yang potensial dipacu berkembang dengan bantuan orang lain atau otomatis melalui aturan atau kedisiplinan. Artinya, dengan bantuan orang lain baik keluarga maupun lingkungan itu yang akan memacu perkembangan moralnya. 3) Tahapan sosionami. Moral berkembang dalam masyarakat. Mereka lebih menaati peraturan kelompok daripada yang berdifat otoritas. 4) Tahap otonomi. Tahapan ini mengenai moral yang mengisi dan mengendalikan kata hatinya sendiri serta kemampuan bebasnya untuk berperilaku tanpa campur tangan orang lain atau lingkungan (Mursid, 2015:79).

Ada pendapat yang mengatakan, anak dilahirkan itu membawa fitrah keagamaan. Fitrah itu baru berfungsi di kemudian hari setelah melalui proses bimbingan dan latihan setelah berada pada tahap kematangan. Di samping itu, perkembangan anak pada usia dini ditandai dengan aspek moralitas heteronom, tetapi pada usia 10 tahun mereka beralih pada suatu tahap yang perkembangannya lebih tinggi yang disebut dengan moralitas otonom (Mursid, 2015:80). Adapun beberapa perilaku bermasalah pada agama dan moral adalah anak nakal, sombong/congkak, berbohong/menipu, bersikap kasar atau tidak sopan, suka membantah perintah orang tua dan guru, kikir, iri, dengki, sulit diajak belajar beribadah, suka berpenampilan vulgar, dan terpengaruh oleh ritual agama lain (Suyadi, 2009:304).

Berdasarkan hasil observasi peneliti di TK A Masyitoh nDasari Budi Yogyakarta, anak berinisial A betingkah laku tidak semestinya. Diantaranya mendorong temannya, merebut mainan teman, berkata kasar pada guru, tidak memperhatikan guru, tidak dapat menghafal doa keseharian, dan belum bisa membaca iqro diusia yang secara aspek bahasa dan kognitif seharusnya sudah mampu melakukan banyak hal. Disis lain, PAUD ini berada di lingkungan pondok pesantren yang kental dengan nilai agama dan moralnya sejalan dengan misi sekolah. Idealnya, anak yang berada di lingkungan yang baik akan tumbuh menjadi anak baik pula. 
Namun muncul sebuah kejanggalan, sebab asusmsi tersebut tidak sesuai dengan kenyataan. Jika dianalisis, kejanggalan tersebut tentu disebabkan oleh beberapa hal.

Berdasarkan uraian dari latar belakang di atas, terdapat beberapa rumusan masalah yaitu: (1) Mengetahui bagaimana perkembangan agama dan moral yang tidak tercapai pada anak umur 5-6 tahun di kelas TK A1 Masyitoh nDasari Budi Yogyakarta. (2) Mendeskripsikan faktor-faktor penyebab perkembangan agama dan moral yang tidak tercapai pada anak usia 5-6 tahun di kelas TK A1 Masyitoh nDasari Budi Yogyakarta.

Selanjutnya menjadi tanggung jawab bersama menganalisis penyebab ketidaktercapaian perkembangan agama dan moral anak tersebut. Harapannya akan ditemukan solusi alternatif sebagai pegangan dalam mendidik anak dan mencegah agar perilaku serupa tidak terjadi kembali. Hal ini penting dilakukan demi menciptakan dan mengembangkan generasi penerus bangsa yang beriman serta ber-akhlakul karimah.

Elizabeth B. Hurlock mengatakan, bahwa minat pada agama dipupuk oleh pendidikan anak di rumah, sekolah, dan penekanan yang diberikan pada kepatuhan terhadap peraturan agama dalam kehidupan sehari-hari. Anak yang dibesarkan dengan kebiasaan berdoa sebelum makan, sebelum tidur, dan orang tuanya membacakan cerita-cerita nabi. Cenderung mempunyai minat yang lebih besar pada agama (Hurlock, 1978:304). Sementara itu, moral diartikan sebagai tata cara, kebiasaan, dan adat istiadat. Perkembangan moral mempunyai aspek kecerdasan dan impulsif. Anak harus belajar apa yang benar dan salah. Selanjutnya setelah mereka cukup besar, mereka harus diberi penjelasan mengapa ini benar dan salah (Hurlock, 1978:75).

\section{METODE PENILITIAN}

Penelitian ini merupakan penelitian kualitatif, yaitu penelitian yang ditunjukkan untuk mendeskripsikan dan menganalisis fenomena, peristiwa, aktivitas sosial, sikap, kepercayaan, persepsi, pemikiran orang secara individual maupun kelompok (Sukmadinata, 2010: 60). Data yang terkait dengan penelitian ini menggunakan studi lapangan. Alasan penggunaan studi lapangan ini melihat bagaimana perkembangan agama dan moral pada anak usia dini yang tidak tercapai, maka membutuhkan beberapa data yang dilihat secara nyata oleh peneliti. Adapun sumber data kualitatif adalah tampilan yang berupa kata-kata lisan atau tulisan yang dicermati oleh peneliti dan benda-benda yang diamati sampai detailnya agar dapat ditangkap makna yang tersirat dalam dokumen atau bendanya (Arikunto, 2010: 22). Dalam pengumpulan data, peneliti menggunakan beberapa teknik, diantaranya: 1) Observasi, merupakan suatu teknik cara pengumpulan data dengan jalan mengadakan pengamatan terhadap kegiatan yang sedang 
berlangsung. (Sukmadinata, 2010: 221). Adapun dalam penelitian menggunakan partisipasi pasif, yaitu peneliti datang di tempat yang diamati langsung, tetapi tidak ikut terlibat dalam kegiatan tersebut (Sugiono, 2014: 311). Observasi yang dilakukan terkait perilaku dan sikap dari perkembangan agama dan moral anak usia dini yang tampak selama proses pembelajaran berlangsung dari awal hingga akhir pembelajaran. 2) Wawancara, merupakan cara untuk memperoleh data dengan jalan mengadakan wawancara dengan narasumber atau responden (Hariwijaya dan Djaelani, 2011: 45). Pada teknik wawancara ini peneliti mewawancari kepala sekolah, wali kelas dan guru pendamping untuk mengetahui bagaimana perilaku dan sikap perkembangan agama dan moral yang tidak tercapai pada anak usia dini, segala proses pembelajaran yang diterapkan di kelas dan orang tua anak yang bersangkutan untuk mengetahui keadaan maupun kegiatan yang dilakukan di rumah. 3) Dokumentasi, merupakan suatu teknik mencari data mengenai hal-hal berupa catatan, buku, data-data yang menunjang penelitian (Arikunto, 2010: 201). Dalam hal ini peneliti menggunakan dokumentasi untuk mendapatkan dari struktur organisasi, sarana dan prasarana, jumlah guru dan karyawan, aktivitas proses pembelajaran di kelas dan data-data lain yang menunjang dalam penelitian ini.

Analisis data dalam penelitian kualitatif, dilakukan pada saat pengumpulan data berlangsung, dan setelah selesai pengumpulan data pada periode tertentu. Dalam penelitian ini menggunakan model Miles dan Huberman, yang mengemukakan bahwa aktivitas dalam analisis data kualitatif dilakukan secara interaktif dan berlangsung secara terus-menerus sampai tuntas, sehingga datanya sudah jenuh. Data jenuh yang dimaksud disini adalah data yang diperoleh peneliti pada batas tertentu selalu sama perolehan data berikutnya. Aktivitas dalam analisis data, yaitu reduksi data, display data, dan verifikasi data (Sugiono: 2014: 337). Adapun penjelasan dari ketiganya adalah sebagai berikut: 1) Reduksi data adalah merangkum, memilih hal-hal yang pokok, memfokukan pada hal-hal yang penting, dicari tema dan polanya. Dengan demikian data yang telah direduksi akan memberikan gambaran yang lebih jelas dan mempermudah peneliti untuk mengumpulkan data selanjutnya serta mempermudah mencarinya bila diperlukan. Reduksi data dapat dibantu dengan peralatan elektronik seperti komputer mini, dengan memberikan kode pada aspek-aspek tertentu. 2) Display data adalah menyajikan data dalam bentuk tabel, grafik, pich card, pietogram dan sejenisnya. Dengan penyajian data tersebut, maka data terorganisasikan, tersusun dalam pola hubungan, sehingga akan semakin mudah difahami. Dalam penelitian kualitatif, pengajian data dapat dilakukan dalam bentuk uraian singkat, bagan, hubungan antar kategori, flowchart dan sejenisnya. 3) Verifikasi data merupakan langkah ketiga 
dari analisis data menurut Miles and Huberman. Kesimpulan awal yang dikemukakan masih bersifat sementara, dan akan berubah jika tidak ditemukan bukti-bukti kuat yang mendukung pada tahap pengumpulan data berikutnya. Tetapi apabila pada kesimpulan yang dikemukakan pada tahap awal, didukung oleh bukti yang valid dan konsisten saat peneliti kembali ke lapangan mengumpulkan data, maka data kesimpulan yang dikemukakan besifat kredibel (Sugiono, 2014: $345)$.

\section{HASIL DAN PEMBAHASAN}

1. Perkembangan Agama dan Moral yang Tidak Tercapai pada Anak di Kelas A1 TK A Masyitoh nDasari Budi Yogyakarta

Analisis perkembangan nilai agama dan moral yang belum tercapai pada subjek ini dilakukan hanya berdasarkan STTPA pada umur 5-6 tahun, sebab subjek yang diteliti berumur 5 tahun. Tingkat perkembangannya dapat diketahui dari hasil pengamatan guru pada saat pembelajaran yang kemudian dideskripsikan dalam raport hasil belajar anak. Berikut tingkatan pencapaian perkembangan moral dan agama pada anak usia dini yang telah ditetapkan oleh BNSP (Wiyani, 2014:179):

\begin{tabular}{|c|c|}
\hline Usia & Perkembangan Moral dan Agama \\
\hline 2-3 tahun & $\begin{array}{l}\text { 1. Meniru gerakan berdoa/sembahyang yang sesuai dengan agamanya } \\
\text { 2. Hafal doa-doa pendek sesuai dengan agamanya } \\
\text { 3. Memahami kapan mengucapkan salam, terima kasih, maaf, dan } \\
\text { sebagainya }\end{array}$ \\
\hline 3-4 tahun & $\begin{array}{l}\text { 1. Memahami perilaku yang berlawanan meskipun belum selalu } \\
\text { dilakukan, seperti baik-buruk, benar-salah, sopan-tidak sopan, } \\
\text { 2. Memahami arti "kasihan" dan "sayang" kepada ciptaan Tuhan }\end{array}$ \\
\hline $4-5$ tahun & $\begin{array}{l}\text { 1. Mengenal Tuhan melalui agama yang dianutnya } \\
\text { 2. Meniru gerakan ibadah } \\
\text { 3. Mengucapkan doa sebelum dan/atau sesudah melakukan sesuatu. } \\
\text { 4. Mengenal perilaku baik/sopan dan buruk. } \\
\text { 5. Membiasakan diri berperilaku baik. } \\
\text { 6. Mengucapkan salam dan membalas salam. }\end{array}$ \\
\hline 5-6 tahun & 1. Mengenal agama yang dianut. \\
\hline
\end{tabular}




\section{Membiasakan diri beribadah.}

3. Memahami perilaku mulia (jujur, penolong, sopan, hormat)

4. Mengenal perilaku baik dan buruk.

5. Mengenal ritual dan hari besar keagamaan.

6. Menghormati agama orang lain.

Gambar 1. Indikator pencapaian perkembangan agama dan moral anak usia dini

Berdasarkan tabel di atas, maka perkembangan moral dan agama pertama kali yang harus dicapai oleh anak usia dini adalah kemampuannya dalam menirukan gerakan sembahyang. Sembahyang dapat diartikan dengan beribadahnya seorang hamba kepada Tuhan sebagai sang Pencipta alam semesta. Kemudian perkembangan agama dan moral anak semakin meningkat hingga umur 5-6 tahun.

Pada usia 2-3 tahun anak sudah bisa dikenalkan dengan rumah ibadah dan perlengkapan ibadah bagi agamanya, serta pengenalan terhadap berbagai gerakan dalam bersembahyang, misalnya saja gerakan-gerakan dalam shalat gerakan-gerakan wudlu. Bagi anak yang berusia 2-3 tahun, doa menjadi pengikat antara anak dengan orang tua dan Tuhannya. Itulah sebabnya di usia tersebut anak mulai bisa diajari untuk menghafalkan doa-doa pendek sesuai dengan ajaran agamanya, seperti doa sebelum tidur dan doa sebelum makan. Dengan pembacaan doa-doa tersebutlah anak mulai dapat merasakan keberadaan Tuhan sebagai sosok yang kuat, yang selalu mewujudkan keinginannya, dan melindunginya (Wiyani, 2014: 180). Kemudian, seseorang dianggap telah mengembangkan aspek moral jika telah menginternalisasikan aturan-aturan atau kaidah serta dapat mengaktualisasikan dalam kehidupan bermasyarakat secara terus-menerus. Adat istiadat kesopanan merupakan bagian dari aspek moral. Agar aspek moral dapat tertanam dengan baik hingga dewasa, maka perlu diberikan sejak dini (Ardini, 2012:45).

Selama proses pembelajaran dan di luar pembelajaran dapat terlihat dengen jelas perkembangan agama dan moral pada subjek A tidak tercapai dengan baik. Dikatakan demikian karena berdasarkan analisis indikator yang harus dicapai pada perkembangan agama dan moral pada anak usia 5-6 tahun, banyak yang tidak terlihat. Adapun uraian indikator perkembangan agama dan moral anak usia dini dengan perilaku dan sikap yang ditunjukkan saat proses pembelajaran dan di luar pembelajaran ada sebagai berikut:

Pertama, mengenal agama yang dianut. Pada tahap pertama berdasarkan penggalian data dari raport anak dan wawancara dengan wali kelas TK A1 bahwa subjek A sudah mengenal 
agama dan Tuhannya yaitu (Allah), walaupun sekedar menyebutkan lewat permainan tepuk. Pada indikator yang pertama dapat dikatakan tercapai namun belum sepenuhnya, sebab hanya menyebutkan ketika bermain "tepuk cinta", sehingga belum merasakan keberadaan Tuhannya. Belajar dengan tepuk merupakan salah satu cara pendidik mengenalkan dan menanamkan nilai agama kepada anak.

Dikatakan oleh Novan Ardy dalam bukunya Perkembangan Psikologi Anak Usia Dini, dikuatkan berdasarkan teori Elizabet B. Hurlock, bahwa pada dasarnya sejak umur 2-6 tahun anak sudah bisa merasakan keberadaan Tuhannya, mengenal Tuhannya, dan mengenal agamanya. Perasaan dan pengenalan tersebut akan semakin luas manakala orang tua maupun pendidik PAUD mengajarkan kepada anak doa-doa harian, menyampaikan cerita-cerita tentang Nabi, membiasakan anak untuk melaksanakan peribadatan maupun mengenalkan berbagai macam praktik ritual serta hari besar keagamaan pada agama yang dianut oleh anak.

Senada dengan deskripsi di atas, kondisi yang terjadi pada subjek A tidak demikian. Berdasarkan sumber data yang didapat dari hasil wawancara dengan orangtua subjek, bahwa orang tua yang tidak mengenalkan tentang Tuhan, apalagi membiasakan aktivitas seperti shalat, membaca doa sehari-hari, dan aktivitas lain yang mendukung. Hal tersebut terjadi karena orangtua sibuk dengan pekerjaannya. Adapun ibunya, sibuk bekerja dari pukul 05.00-22.00 WIB dan ayahnya sebagai karyawan yang sibuk bekerja dari jam 06.00-16.00 WIB. Kondisi ini berjalan sejak subjek A masih berumur dua tahun sampai sekarang. Sehingga jelaslah, berdampak buruk seiring dengan tumbuh-kembang anak.

Kedua, membiasakan diri beribadah. Pada tahapan ini, subjek A belum mencapainya. Berdasarkan hasil wawancara dengan kepala sekolah dan guru pendamping kelas, A belum mengetahui bacaan dan gerakan shalat. Hal tersebut ditunjukkan saat pembelajaran berlangsung. Seperti yang sudah dijelaskan sebelumnya, bahwa A tidak diajarkan shalat oleh kedua orang tuanya. Padahal peran orang tua bagi pertumbuhan anaknya sangat penting apalagi menyangkut agama sebagai keyakinan utama yang harus ditanamkan kepada anak sejak usia dini. Pernyataan di atas memang sangat berbeda dengan pendidikan agama yang harus diberikan oleh orang dewasa pada masa tersebut. Sejalan dengan apa yang disampaikan oleh Novan Ardy dalam bukunya Psikologi Pemkembangan Anak Usia Dini, bahwa masa perkembangan moral dan agama pertama kali yang harus dicapai oleh anak usia dini adalah kemampuannya dalam menirukan gerakan sembahyang. Sembahyang dapat diartikan dengan beribadahnya seorang hamba kepada Tuhan sebagai Sang Pencipta alam semesta. Pada usia 2-3 tahun anak sudah bisa 
dikenalkan dengan rumah ibadah dan perlengkapan ibadah bagi agamanya, serta pengenalan terhadap berbagai gerakan dalam bersembahyang, misalnya saja gerakan-gerakan dalam shalat gerakan-gerakan wudlu. Bagi anak yang berusia 2-3 tahun, doa menjadi pengikat antara anak dengan orang tua dan Tuhannya. Sehingga dapat dikatakan, idealnya tahapan kedua ini sudah dicapai oleh subjek A bahkan sudah membiasakannya dalam kehidupan sehari-hari.

Ketiga, memahami perilaku mulia (jujur, penolong, sopan, hormat, dan lain sebagainya). Berdasarkan hasil pengamatan saat proses pembelajaran berlangsung, ketika membaca doa belajar subjek A tengah bermain sendiri. Kemudian ketika kegiatan mendengarkan cerita tidak memperhatikan dengan baik justru berkeliling kelas dan bermain dengan barang-barang disekitar kelas, sehingga mengganggu konsentrasi anak lain yang sedang mendengarkannya. Pada kegiatan mewarnai, subjek A melakukannya dengan cepat walaupun masih terlihat acak-acakan dan gambar yang diwarnai tidak sesuai dengan intruksi yang diberikan oleh pendidik. Kemudian saat kegiatan mewarnai tersebut, terlihat sikap yang kurang sopan ketika pendidik memberikan pertanyaan, namun pertanyaan tersebut dijawab dengan suara keras di depan wajah pendidik. Perilaku dan sikap yang tidak sopan berlanjut dengan mengambil buku temannya secara paksa serta meyenggol dan mencoret gambar milik temannya. Berdasarkan penjelasan di atas, dapat disimpulkan bahwa ia belum memahami tentang perilaku maupun sikap mulia atau baik.

Keempat, mengenal perilaku baik dan buruk. Perilaku yang ditunjukkan oleh subjek A kepada temannya menunjukkan bahwa ia belum memahami mana perilaku yang baik dan buruk. Sebab ketika melakukan sesuatu yang merugikan orang lain, tidak mempertimbangkan konsekuensi yang akan didapat walaupun memang pada masa ini ia berada pada masa egosentrisme. Kemudian perilaku dan sikap tidak baik kepada guru dan temannya tersebut, seperti hal yang sudah biasa. Sehingga ketika guru memberikan sedikit penekanan kepada A tidak memberikan pengaruh, justru melawan dan melakukannya kembali.

Sejalan dengan deskripsi tersebut, sejatinya pendidikan anak harus dilakukan melalui tiga lingkungan, yaitu keluarga, sekolah, dan organisasi. Keluarga merupakan pusat pendidikan yang pertama dan terpenting. Sejak timbulnya peradaban manusia sampai sekarang, keluarga selalu berpengaruh bersar terhadap perkembangan anak manusia. Pendidikan adalah tanggung jawab bersama antara keluarga, masyarakat, dan pemeritah. Sekolah sebagai pembantu kelanjutan pendidikan anak dalam keluarga sebab pendidikan yang pertama dan utama diperoleh anak adalah keluarga. Perlunya kerjasama antara keluarga dan sekolah. Sikap anak terhadap sekolah akan dipengaruhi oleh sikap orang tua mereka. Oleh karena itu, diperlukan kepercayaan orang 
tua terhadap sekolah (pendidik) yang menggantikan tugasnya selama di sekolah. Orang tua harus memperhatikan sekolah anaknya dengan memperhatikan pengalaman-pengalamannya dan menghargai usaha-usahanya serta menunjukkan kerja samanya dalam cara anak belajar di rumah atau membuat pekerjaan rumahnya (Hasan, 2013:19).

Lain halnya dengan penjelasan Elizabet B. Hurlock melalui bukunya perkembangan anak, menyatakan bahwa moralitas yang sesungguhnya jarang ditemukan pada anak, tetapi ia harus muncul selama masa remaja. Jika melihat secara teori, perkembangan moral mempunyai aspek kecerdasan dan impulsif. Anak harus belajar apa saja yang benar dan yang salah. Selanjutnya segera setelah mereka cukup besar, mereka harus diberikan penjelasan mengapa ini benar dan itu salah. Mereka juga harus mempunyai kesempatan untuk mengambil bagian dalam kegiatan kelompok sehingga mereka dapat mengenal harapan kelompok. Lebih penting lagi, mereka harus mengambangkan keinginan untuk melakukan hal yang benar, bertindak untuk kebaikan bersama dan menghindari yang salah (Hurlock, 1978:75). Untuk melaksanakan aspek perkembangan nilai agama dan moral, guru memiliki andil sangat besar dalam membimbing anak di dalam kelas, terutama dalam membedakan baik dan buruk. Guru memberikan arahan tentang perilaku yang baik dalam sehari-hari dan gambaran akibat perilaku yang buruk (Amelia dkk, 2013:2).

Sementara itu, perkembangan moral pada kanak-kanak masih dalam tingkat yang rendah. Hal ini disebabkan karena perkembangan intelektual anak-anak belum mencapai titik di mana ia dapat mempelajari atau menerapkan prinsip-prinsip abstrak tentang benar dan salah. Menurut Piaget dan Kohlberg yang didukung oleh Hurlock, dijelaskan bahwa perkembangan moral; bergantung dari perkembangan kecerdasan. Ia terjadi dalam tahapan yang dapat diramalkan yang berkaitan dengan tahapan perkembangan kecerdasan. Dengan berubahnya kemampuan menangkap dan mengerti, anak-anak bergerak ketingkat perkembangan moral yang lebih tinggi. (Hurlock, 1978:75). Bedasarkan pernyataan dari guru kelas, bahwa secara kognitif A belum berkembang dengan baik.

Kelima,mengenal ritual dan hari besar keagamaan. Ketika membicarakan ritual berarti sedang membicarakan kebiasaan yang dilakukan oleh agama tertentu. Mengenai hal ini, subejak A mengetahui bahwa harus membaca doa sebelum belajar, setelah belajar ,makan dan minum serta mengetahui bahwa ada hafalan surat pendek dan doa sehari-hari. Namun yang menjadi permasalahan bahwa subjek A belum hafal do'a-do'a tersebut kecuali doa akan tidur. Adapun mengenai hari-hari besar agama Islam, ia juga belum mengetahui dan memahaminya. 
Senada dengan apa yang disampaikan oleh Elizabet B. Hurlock bahwa minat pada agama dipupuk oleh pendidikan anak di rumah, penekanan yang diberikan kepada kepatuhan terhadap peraturan agama dalam kehidupan sehari-hari. Anak-anak yang dibesarkan dengan dibiasakan berdo'a sebelum makan, yang harus berdo'a sebelum tidur, dan yang orangtuanya membacakan dan menceritakan cerita-cerita religius, cenderung mempunyai minat yang lebih besar pada agama. Sekiranya pernyataan di atas jelas bahwa minat perkembangan agama yang ada pada subjek A merupakan hasil pendidikan keluarga yang sangat minim.

Keenam, menghormati agama orang lain. Adapun basis PAUD ini adalah agama Islam dan berada di lingkungan pesantren sehingga berfokus pada penanaman tentang nilai-nilai Islam. Sementara penanaman toleransi di lingkungan PAUD ini salah satunnya adalah menghargai atau peduli kepada teman. Melihat kembali apa yang sudah dijelaskan di atas perilaku dan sikap yang kurang baik oleh subjek A kepada temannya menunjukkan bahwa belum tertanamnya sikap toleransi kepada orang lain.

Perilaku dan sikap yang ditunjukkan subjek A merupakan hal yang memprihatinkan. Sebab jika sampai saat ini masih berlanjut, maka kemungkinan besar akan berpengaruh pada saat ia dewasa. Sehingga hal ini menjadi permasalahan serius untuk ditangani. Padahal melihat dari segi pendidiknya yaitu wali kelas dan pendampinya sudah memenuhi kualifikasi guru PAUD sebagai sarjana strata satu (S1) dan kemampuan mengajar yang baik ditunjukkan dengan penggunaan metode pembelajaran yang cukup bervariasi serta pecinta anak-anak. Disisi lain, dari segi manajemen kelas kurang tertata dengan baik dapat dilihat dari ruangan yang masih sepi dan barang-barang yang belum tertata dengan rapi. Padahal kondisi kelas juga amat mendukung proses pembelajaran.

2. Faktor-faktor Perkembangan Agama dan Moral Yang Tidak Tercapai Pada Anak Di Kelas A1

TK Masyitoh nDasari Budi Yogyakarta.

Berdasarkan deskripsi di atas, maka secara garis besar dapat disimpulkan terdapat dua faktor perkembangan agama dan moral yang tidak tercapai pada subjek A. Adapun faktor inilah yang kemudian akan menjadi pertimbangan mengenai solusi alternatif untuk menyelesaikan masalah tersebut. Faktor perkembangan agama dan moral yang tidak tercapai pada subjek A dapat dilihat pada gambar berikut; 


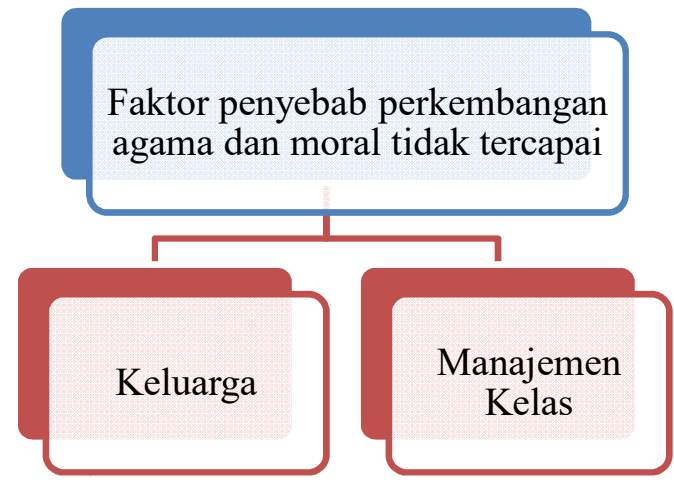

Gambar 2. Faktor perkembangan agama dan moral yang tidak tercapai pada subjek A

Gambar di atas menunjukkan bahwa penyebab perkembangan agama dan moral pada subjek A terjadi karena dua faktor. Adapun deskripsi dua faktor tersebut sebagai berikut;

Pertama, keluarga. Rumah yang di dalamnya sebuah keluarga adalah madrasah atau sekolah utama bagi anak. Hal ini berimplikasi bahwa orang tua merupakan guru pertama bagi anak, termasuk dalam kategori guru pertama bagi anak ini adalah kakek, nenek, dan orang-orang yang lebih dewasa dalam rumah tersebut. Oleh karena itu, persepsi rumah dan lembaga PAUD harus selaras, sehingga rumah menjadi sekolah awal sebelum masuk PAUD (Suyadi dan Ulfah, 2013:149-150).

Sama halnya dengan demikian, bahwa peranan orang tua bagi pendidikan anak adalah memberikan dasar pendidikan, sikap, dan keterampilan dasar, seperti pendidikan agama, budi pekerti, sopan-santun, estetika, kasih-sayang, rasa aman, dasar-dasar untuk memenuhi peraturan, dan menanamkan kebiasaan-kebiasaan. Selain itu, peranan keluarga adalah mengajarkan nilainilai dan tingkah laku yang sesuai dengan yang diajarkan di sekolah. Dengan kata lain, ada kontinuitas antara materi yang diajarkan dengan di rumah dan materi yang diajarkan di sekolah. Pentingnya peranan orang tua dalam pendidikan anak telah disadari oleh banyak pihak (Hasan, 2013:19).

Kaitannya dengan penjelasan di atas, berdasarkan hasil penelitian dapat diketahui penyebab perkembangan agama dan moral subjek A salah satunya karena kurang pendidikan, kedekatan, dan perhatian orang tua. Adapun sejak usia dua tahun, A sudah dititipkan kepada kakek dan neneknya. Hal tersebut sengaja dilakukan sebab kedua orang tuanya sibuk dengan pekerjaan untuk membayar kontrakan dan untuk memenuhi kebutuhan sehari-hari. Setelah genap enam tahun dan dirasa A sudah besar kemudian memasukannya ke taman kanak-kanak. Oleh karena tuntutan sebuah pekerjaan, waktu kebersamaan keluarga A sangat minim. Hal tersebut 
dapat terlihat dari aktivitas sehari-hari bahwa setiap pagi pukul 07.00 WIB, A diantarkan ke sekolah oleh ayahnya dan dijemput oleh ibunya. Sepulang sekolah subjek bermain di tempat kerja ibunya, setelah tepat pukul 16.00 WIB ayahnya menjemput untuk kembali ke kontrakan. Pernyataan lain juga menunjukkan bahwa Ibu A bekerja dari jam 06.00-22.00 WIB lebih lama dibandingkan dengan ayahnya yang bekerja dari jam 07.00-16.00 WIB. Karena padatnya pekerjaan Ibu A sehingga aktivitas yang berkaitan dengan anaknya dilakukan oleh ayahnya, termasuk memandikan. Selain itu, minimnya kebersamaan keluarga tersebut, sehingga tidak memiliki waktu untuk mengajarkan kepada anaknya beberapa hal seperti; membaca al-Qur'an, doa sehari-hari, shalat lima waktu dan lain sebagainya.

Seperti yang sudah diketahui bersama, bahwa rumah adalah madrasah atau sekolah pertama bagi anak. Hal ini berimplikasi bahwa orang tua merupakan guru pertama bagi anak. Oleh karena itu, persepsi rumah dan lembaga PAUD harus selaras, sehingga rumah menjadi sekolah awal sebelum masuk PAUD. Dengan demikian, rumah yang di dalamnya (orangtua) tidak harmonis, bahkan rusak (broken home) tidak akan bisa menjadi "sekolah" pertama yang efektif bagi anak karena keluarga sebagai "sekolah" pertama telah rusak dan dengan demikian anak ikut rusak. PAUD tempat anak-anak yang rusak tersebut juga tidak akan berjalan efektif karena anak yang rusak sulit diajak bermain, bersosialisasi, bernyanyi, dan lain sebagainya. Inilah mengapa kunci efektivitas PAUD tergantung pada aktivitas rumah sebagai "sekolah" pertama bagi anak (Suyadi dan Ulfah, 2013:149-150).

Lebih dari itu, konsekuensi yang tidak dapat dihindari jika "sekolah" pertama rumah, otomatis "guru" pertama adalah orang tua mereka. Kaidah ini (orang tua sebagai guru pertama) berlaku secara kodrati. Artinya orang tua tidak memiliki pilihan lain kecuali menjalankan tugasnya sebagai pendidik atas anak-anak yang mereka lahirkan. Oleh karena itu, keharmonisan rumah tangga memberikan kontribusi sangat besar bagi keberhasilan pendidikan di keluarga tersebut. Bahkan, jika suatu keluarga mengalami kerusakan, korban pertama adalah anak-anak, bukan orang tua (Suyadi dan Ulfah, 2013:151).

Lain halnya dengan penjelasan di atas, berdasarkan hasil analisis dari pernyataanpernyataan yang telah disampaikan, bahwa orang tua A belum memahami dengan baik peran orang tua yang sangat penting bagi pertumbuhan dan perkembangan anak. Padahal interaksi sosial awal terjadi dalam keluarga. Anak belajar dari orang tua, saudara kandung, dan anggota keluarga lain apa yang dianggap benar dan salah oleh kelompok sosial tersebut. Dari penerimaan sosial atau penghargaan bagi perilaku yang benar, anak memperoleh perilaku yang 
diperlukan untuk mengikuti standar perilaku yang ditetapkan anggota keluarga (Hurlock, 1978:78). Dalam artian peraturan yang ditetapkan keluarga menjadi pegangan anak dalam berperilaku.

Senada dengan hal tersebut, dapat diketahui bahwa selama ini subjek A bersosialiasi hanya pada dua tempat yaitu rumah dan tempat bekerja ibunya. Perlu diketahui bersama, satu pokok dalam belajar menjadi orang yang bermoral ialah mempunyai kesempatan melakukan interaksi dengan anggota kelompok sosial. Masuknya cakrawala sosial sampai ke lingkungan luar rumah dan sekolah, anak-anak melalui permainan dan komunikasi dengan teman sebaya mulai belajar bahwa beberapa standar perilaku yang dipelajari mereka di rumah sama dengan standar teman sebaya dan beberapa lain berbeda. Sebagai contoh, mereka mungkin melihat bahwa mengadukan perbuatan teman kepada orang tua tidak saja diterima, tetapi disetujui orang tua, tetapi dalam kelompok sebaya hal ini sangat tidak disetujui.

Dengan meningkatnya interaksi sosial dengan teman sebaya, pengaruh mereka bertambah pula. Bila terdapat perbedaan antara standar moral di rumah dan standar kelompok teman sebaya, anak-anak sering menerima standar teman sebaya dan menolak standar keluarga. Melalui interaksi sosial, anak tidak saja mempunyai kesempatan untuk belajar, kode moral, tetapi mereka juga mendapat kesempatan untuk belajar bagaimana orang lain mengevaluasi perilaku mereka (Hurlock, 1978: 78).

Sebagaimana dikatakan bahwa diantara penyebab mengapa anak yang tidak melakukan hal positif dalam keterkaitan interaksi dengan orang lain adalah kurangnya pendidikan orang tua atau imitasi yang tidak tepat, sehingga memunculkan perilaku yang kurang sesuai dengan norma dan aturan setempat(Setiawati, 2006:42). Anak-anak tumbuh dan berkembang dalam kehidupan yang diwarnai oleh pelanggaran terhadap hak orang lain, kekerasan, pemaksaan, ketidakpedulian, kerancuan antara benar dan salah, baik dan tidak baik, perilaku yang boleh dan tidak boleh dilakukan. Banyak masalah yang diselesaikan dengan kekerasan, adu kekuatan fisik, dan mengabaikan cara penyelesaian dengan mengandalkan pertimbangan moral (Ahyani, 2010:24). Jika warna kehidupan tersebut tidak dipahami oleh orang tua karena kurangnya pengetahuan tentang pendidikan anak, maka akan memungkinkan dampak buruk dapat terjadi, sebab tidak adanya pengawasan maupun pencegahan sebagai bekal bersosialisasi di lingkungan sekitarnya.

Kedua, manajemen kelas. Permasalahan yang terjadi pada subjek A tentu berpotensi mengganggu situasi di dalam kelas, sehingga suasana berubah menjadi tidak kondusif. Di sisi 
lain, sebagian besar pendidik memfokuskan penyebab masalah kelas yang tidak kondusif tersebut hanya kepada anak didiknya. Sebenarnya, tidak dipungkiri masalah tersebut dapat terjadi karena kurangnya kompetensi pendidik dalam mengatasi perilaku yang tidak mencerminkan nilai agama dan moral. Adapun pendidik di TK A Masyitoh nDasari Budi ini tidak melakukan pendekatan secara personal yang mengajak anak berbicara baik-baik. Namun, lebih banyak memberikan intruksi yang membuat anak merasa jenuh dan pada akhirnya anak mengulangi perilaku yang sama. Selain itu, pendidik kurang melibatkan orang tua dalam masalah pendidikan subjek, dengan alasan khawatir akan mengganggu pekerjaan orang tuanya. Oleh karena itulah, pendidik hanya melaporkan perkembangan anak melalui raport.

Beberapa penelitian menemukan fakta bahwa anak yang sering berbuat onar dalam kelas, biasanya memiliki suatu masalah yang berkaitan dengan keluarganya. Dalam hal ini, guru harus menjelaskan secara gamblang perilaku anak kepada orang tua yang bersangkutan, untuk kemudian diupayakan solusi bersama. Mengajak orang tua untuk berdiskusi dari hati-hati mengenai masalah-masalah di rumah tangga yang mungkin turut memicu kenakalan anak. Dengan melibatkan orang tua, maka akan muncul rasa saling pengertian dan keinginan untuk membantu antara guru, siswa, dan orang tua. Sinergi diantara ketiga pihak inilah yang memungkinkan terwujudya cita-cita pendidikan (Rusydie, 2011:80-81).

Adapun berdasarkan hasil analisis, bahwa perilaku dan sikap yang ditunjukkan oleh subjek berinisial A disebabkan karena kurangnya pendidikan dan kasih sayang yang diberikan orang tuanya. Seperti yang diketahui bersama, bahwa orang tua merupakan madrasah utama, sehingga sebaik dan semaksimal apapun pendidikan yang diberikan oleh guru, anak tidak akan tumbuh optimal jika tidak didorong oleh kasih sayang dan pendidikan dari orang tua.

Golden age merupakan sebuah masa yang tidak akan pernah terulang kembali dari kehidupan setiap manusia. Di masa inilah anak sangat perlu stimulasi untuk mengembangkan potensi-potensi yang ada pada dirinya. Yang kemudian akan menumbuhkan rasa percaya diri, kreatif, berani dan sifat positif lainnya. Adapun stimulasi itu berasal dari orang-orang terdekat anak seperti teman, guru, dan yang paling utama adalah orang tua sebagai orang yang paling mengetahui kebutuhan dan kondisi anak. Sehingga demi perkembangan dan pertumbuhan yang baik pada anak, pendidik harus bersikap lebih tegas dengan melakukan kerjasama yang baik dengan orang tua anak. 


\section{DAFTAR PUSTAKA}

Ardy Wiyani, Novan. (2014). Psikologi Perkembangan Anak Usia Dini. Yogyakarta: Gava Media. 2014. Konsep Dasar PAUD. Yogyakarta: Gava Media

Arikunto, Suharsimi. 2010. Prosedur Penelitian. Jakarta:Rineka Cipta.

B. Hurlock, Elizabth. (1978). Teori Perkembangan. Yogyakarta: Mei Meitasari Thang Tjangdrasa.

G. Gunarsah, Singgih. (2003). Psikologi Perkembangan. Jakarta: PT. BPK Gunung Mulia. Hariwijaya, M dan Bisri M Djaelani. 2011. Panduan Menyusun Skripsi. Yogyakarta: Siklus. Hasan, Maimunah. (2013). Pendidikan Anak Usia Dini. Jogjakarta: DIVA Press.

Syantut, Khatib Ahmad. (1998). Menumbuhkan Sikap Sosial, Moral dan Spiritual Anak dalam Keluarga Muslim. Yogyakarta: Mitra Pustaka.

Mansur. (2011). Pendidikan Anak Usia Dini dalam Islam. Yogyakarta: Pustaka Pelajar.

Mursid. (2015). Belajar dan Pembelajaran. Bandung: PT. Remaja Rosdakarya.

Rusydie, Salman. (2011). Prinsip-prinsip Manajemen Kelas. Yogyakarta: DIVA Press

Santrock, John W. (2007). Perkembangan Anak. Jakarta : Erlangga

Sukmadinata, Nana Syaodih. (2010). Metode Penelitian Pendidikan. Bandung: PT. Remaja Rosydakarya.

Sugiono. (2014). Metode Penelitian Kombinasi. Bandung: Alfabeta.

Suyadi dan Maulidya Ulfa. (2013). Konsep Dasar PAUD. Bandung: Remaja Rosydakarya.

Yudrik Jahja. (2011). Psikologi Perkembangan. Jakarta: Prenada Media Group.

Agus Setiawati, Farida. (2006). "Pendidikan Moral dan Nilai-nilai Agama pada Anak Usia Dini: Bukan Sekedar Rutinitas", dalam Jurnal Paradigma No.2 Tahun 1, Juli. Hal. 42

Amelia, Nony, dkk. (2013). "Peningkatan Perkembangan Nilai Agama dan Moral". Dalam http://download.portalgaruda.org/article.php?article=112416\&val=2338, di akses tanggal 24 Juli 2017

Kadek Novia Purmamasari, Ni, dkk. (2014). "Penerapan Metode Demonstrasi Melalui Kegiatan Melipat Kertas (Origami) untuk Meningkatkan Perkembangan Motorik Halus Anak", dalam e-Journal PAUD Universitas Pendidikan Ganesha, Vol. 2, No. 1, Hal. 2

Nur Ahyani, Latifah. 2010. "Metode Dongeng dalam Meningkatkan Perkembangan Kecerdasan Moral Anak Usia Prasekolah", dalam Jurnal Psikologi Universitas Muria Kudus, Volume 1, No. 1, Desember. Hal. 24

Puspa Ardini, Pupung. 2012. "Pengaruh Dongeng dan Komunitas Terhadap Perkembangan Moral Anak Usia 7-8 Tahun", dalam Jurnal Pendidikan Anak, Volume 1, Edisi 1, Juni, Hal. 45

Rantina, Wahyuni. 2012. "Pembelajaran Agama di Sentra Iman dan Taqwa Taman Kanak-Kanak Huffazh Payakumbuh", dalam Jurnal Pesona PAUD, Vol. 1, No.05

Survey RI-UNICEF: 1,5 Juta Remaja Alami Kekerasan Seksual 1 Tahun Terakhir, di akses dari http://news.detik.com/berita/2584418/survei-ri-unicef-15-juta-remaja-alami-kekerasanseksual-1-tahun-terakhir, di akses pada tanggal 28 Juli 2017

Syamsudin, Amir. 2016. "Evaluasi Ketercapaian Standar Isi Perkembangan Nilai-nilai Agama dan Moral Anak Usia Dini Pada Semester Gasar 2016/2017 KB/TK PEDAGOGIA", dalam Jurnal Pendidikan Anak, Vol. 5, Edisi 2, Desember, Hal. 765 
Yan Yusuf, Kekerasan Anak Masih Jadi Momok yang Menakutkan. Di akses dari https://metro.sindonews.com/read/1114783/170/kekerasan-anak-masih-jadi-momokyang-menakutkan-1465301215, di akses pada tanggal 28 Juli 2017

Yusuf, Muhammad. 2014. "Pendidikan Karakter Berbasis Qur'ani dan Kearifan Lokal", dalam Jurnal Karsa, Vol. 22, No. 1, Hal. 54 